PontIFícIA UNIVERSIDADE CATÓLICA DO RIO DE JANEIRO

Análise do Mercado de Transportes de carga no Brasil Vantagem Competitiva no modal rodoviário

Igor Moreira Oliveira Dantas

Trabalho de Conclusão de Curso

Centro de CIÊnCIAS SOCIAIS - CCS

DEPARTAMENTO DE AdMINISTRAÇÃO

Graduação em Administração de Empresas 
Igor Moreira Oliveira Dantas

\section{Análise do Mercado de Transportes de carga no Brasil Vantagem Competitiva no modal rodoviário}

Trabalho de Conclusão de Curso

Trabalho de Conclusão de Curso, apresentado ao programa de graduação em Administração da PUC-Rio como requisito parcial para a obtenção do título de graduação em Administração.

Orientador(a): Marco Aurélio de Sá Ribeiro 


\section{Agradecimentos}

Em vista da presença de tantas pessoas em minha vida pessoal e acadêmica, gostaria de agradecer aos seguintes:

Meus pais, Wagner e Silvana, por todo o amor, esforço realizado em minha formação como indivíduo e suporte para possibilitar a conclusão do curso de Administração de Empresas. Obrigado por estarem ao meu lado em todas as decisões e momentos de dificuldades bem como os de felicidade.

Meu irmão, Wagner Junior, por todo o amor, cuidado e carinho comigo e também por sempre, mesmo que de maneiras implícitas, me aconselhar de acordo com o que acredita ser melhor para mim.

Minha namorada, Duda, que me ajudou com seu amor, inteligência e companheirismo a concluir o curso e compreendeu os momentos de ausência devido as atividades necessárias para minha formatura.

Também agradeço a todos os amigos, professores e demais funcionários da instituição com que tive o prazer de conviver na Pontifícia Universidade Católica, certamente tê-los conhecido foi de grande contribuição para meu desenvolvimento pessoal e profissional. Em especial, sou grato por ter conhecido e trabalhado com Pedro Cruz e Lucas Oliveira.

Reconheço a importância também dos avós, tios(as), padrinhos, primos, amigos e professores não citados aqui e que conheci fora da instituição de ensino PUC Rio. O contato com todos vocês foi importante para moldar a pessoa que sou hoje. Sou grato por ter conhecido, conversado, aprendido e amado vocês. 


\section{Resumo}

Moreira, Igor. Análise do Mercado de Transportes de carga no Brasil Vantagem Competitiva no modal rodoviário. Rio de Janeiro, 2020. 31 p. Trabalho de Conclusão de Curso - Departamento de Administração. Pontifícia Universidade Católica do Rio de Janeiro.

O artigo foi escrito com o intuito de entender quais recursos geram vantagem competitiva sustentável para transportadoras de carga do modal rodoviário. Para entender a realidade do setor, foi realizado uma análise de mercado. Em seguida, foram realizadas entrevistas qualitativas com profissionais atuantes no setor e os dados foram utilizados para montar a cadeia de valor de uma transportadora de pequeno porte e também para listar os principais recursos presentes na mesma, que foram então analisados segundo o modelo VRIO para compreender quais geram ou não a vantagem competitiva para a empresa.

\section{Palavras- chave}

Análise VRIO, cadeia de valor, modal rodoviário, transporte de cargas, diferenciação, vantagem competitiva.

\section{Abstract}

Moreira, Igor. Analysis of the Brazilian Cargo Transport Market Competitive Advantage in the road modal. Rio de Janeiro, 2020. 31 p. Course conclusion work - Department of Administration. Pontifícia Universidade Católica do Rio de Janeiro.

This article was written with the purpose of understanding which resources generate a sustainable competitive advantage for road cargo transport companies. To understand sector reality, it was done a market analysis. Following, qualitative interviews were conducted with professionals currently working in the sector. The data generated by the interviews was used to build a value chain scheme of a small-sized cargo transport company and to list the main resources identified in the company. then, this list was analyzed according to the VRIO analysis model to determine if the feature generates or not sustainable competitive advantage. 
VRIO analysis, value chain, cargo, transport market, differentiation, competitive advantage. 


\section{Sumário}

1. Introdução 1

1.1. Contexto 1

1.2. Objetivo e Delimitação 4

1.3. Relevância 4

2. Referencial Teórico 5

2.1. Cinco Forças de Porter 5

2.1.1. Concorrência na Indústria 6

2.1.2. Poder de Barganha dos Consumidores 6

2.1.3. Poder de Barganha dos Fornecedores $\quad 7$

2.1.4. Ameaça de Novos Entrantes 7

2.1.5. Ameaça de Produtos Substitutos 8

2.2. Cadeia de Valor 8

2.3. Modelo VRIO 9

2.3.1. Valor 9

2.3.2. Raridade 9

2.3.3. Imitabilidade 9

$\begin{array}{ll}\text { 2.3.4. Oportunidade } & 10\end{array}$

3. Metodologia 11

3.1. Coleta de dados 11

3.2. Tratamento e análise de dados 12

3.3. Limitação do estudo 12

4. Apresentação e análise dos resultados 13

4.1. Análise do Setor 13

$\begin{array}{lr}\text { 4.1.1. Concorrência no Setor } & 13\end{array}$

$\begin{array}{ll}\text { 4.1.2. Poder de Barganha dos Consumidores } & 13\end{array}$

4.1.3. Poder de Barganha dos Fornecedores 14

4.1.4. Ameaça de Novos Entrantes 16 
4.1.5. Ameaça de Produtos Substitutos 17

$\begin{array}{ll}\text { 4.2. Cadeia de Valor do negócio } & 17\end{array}$

4.2.1. Processos de Apoio 17

$\begin{array}{ll}\text { 4.2.1.1. Infraestrutura } & 17\end{array}$

4.2.1.2. Gestão de Pessoal 18

4.2.1.3. Gestão Administrativa Financeira 18

$\begin{array}{ll}\text { 4.2.2. Processos Primários } & 19\end{array}$

4.2.2.1. Atendimento Comercial e Vendas 19

4.2.2.2. Processos de Coletas 19

4.2.2.3. Tratamento de Cargas 19

4.2.2.4. Viagens e Transferências 20

4.2.2.5. Processos de Entrega 20

$\begin{array}{ll}\text { 4.2.3. Margens } & 21\end{array}$

4.3. Análise VRIO 21

4.3.1. Adaptabilidade ao cliente 21

4.3.2. Confiabilidade do serviço 22

4.3.3. Tecnologia da informação 23

4.3.4. Infraestrutura própria 24

4.3.5. Instrumentos de segurança 25

4.3.6. Preço 26

$\begin{array}{ll}\text { 4.3.7. Identidade empresarial } & 27\end{array}$

5. Conclusão 29

6. Referências Bibliográficas 32

7. Anexo 34

7.1. Entrevista Qualitativa com Diretores/Presidentes da transportadora 34

7.2. Entrevista Qualitativa com Funcionários da transportadora 35

7.3. Entrevista Qualitativa com Clientes da transportadora 36 


\section{Índice de figuras}

Figura 1 - Modelo das Cinco Forças de Porter 5

Figura 2 - Cadeia de Valor de Porter 8

Figura 3 - Cadeia de Valor da transportadora Exatidão Express 21

\section{Índice de gráficos}

Gráfico 1 - Distribuição de TKU por modal $\quad 2$

Gráfico 2 - Evolução do número de ocorrências de Roubos de Cargas no estado do Rio de Janeiro 3

Gráfico 3 - Preço do Litro de Óleo Diesel 16

\section{Índice de tabelas}




\section{Introdução}

\subsection{Contexto}

Cerca de $39 \%$ da população brasileira economicamente ativa é dona do seu próprio negócio (Consultoria McKinsey, 2019) e são iniciadas no país diariamente, em média, mais de 6,8 mil empresas (2,5 milhões ao longo de 2018) (Serasa Experian, 2019). Porém, 24,4\% destes negócios fecham as portas antes de completarem seu segundo aniversário e metade das empresas não sobrevivem até completar quatro anos (Sebrae, 2013). No cenário brasileiro, isto é, atribuído principalmente a dificuldade de planejamento e formulação de estratégia para negócios emergentes (Sebrae, 2013).

Ludwin Bertalanffy (1937) descreve, através da Teoria de Sistemas, uma empresa como um conjunto de partes que se comunicam e relacionam para atingir um objetivo final (Oliveira, 2018). Para tal, a empresa deve idealizar e organizar estrategicamente todos seus recursos de maneira que maximize as chances de cumprimento de suas metas. Apesar de autores divergirem na metodologia, a atitude de preparar uma organização para os dias futuros é chamada de Planejamento ou Plano Estratégico (Kotler \& Keller, 2012).

Ao redor do mundo, o setor nacional de transporte de cargas é segmentado em cinco partes, que são as maneiras como o transporte é realizado. Cada um tem suas peculiaridades em relação a custos, riscos e necessidades, são elas:

- Rodoviário - Realizado através de estradas e rodovias, geralmente por caminhões. Gera altos custos com combustíveis e ganho de escala inexistente. Grande versatilidade.

- Aquaviário - Realizado em mares, rios e lagos, geralmente por embarcações médias e grandes. Grande potencial no Brasil (grande malha hidroviária). Economia de escala.

- Ferroviário - Realizado através de vias férreas por trens. Carece de investimentos no país e por isso é sucateado. Possibilita uma economia de escala. Possui uma grande capacidade 
- Aéreo - Realizado por aeronaves. Limitado em tamanho, peso e volume da carga. Altos custos podem ser compensados pela baixa variabilidade do tempo de entrega. Geralmente depende de uma conexão com algum outro modal para finalizar o transporte.

- Dutoviário - Realizado através de tubos e dutos que podem ser submarinos ou aparentes, utilizado em caso de produtos líquidos ou maleáveis como Petróleo ou gás natural. Possui alta capacidade e grande economia de escala. Porém requer um investimento inicial elevado e não possui flexibilidade nas rotas.

(Fonte: TRUCKPAD, 2017)

O boletim estatístico da Confederação Nacional do Transporte (CNT) nos mostra que, em 2018, a distribuição entre estes modelos se apresentou da seguinte maneira:

\section{Gráfico 1 - Distribuição de TKU por modal}

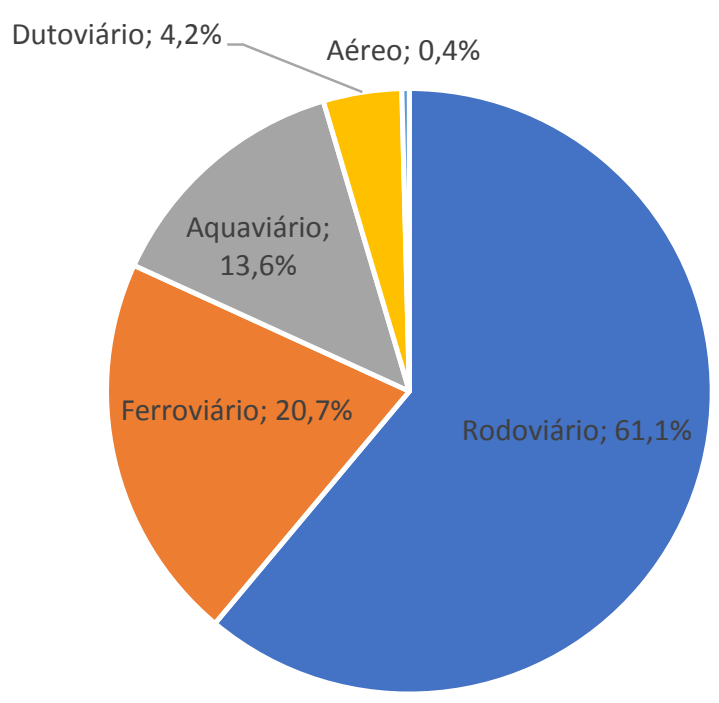

Fonte: Boletim Estatístico CNT 2018

Em 2018, o modal de transporte rodoviário de cargas no Brasil contava com mais de 147 mil empresas (CNT, 2019), sendo considerado amplamente pulverizado. Frequentemente, a disputa entre estas empresas se resume a oferecer o melhor preço ao cliente, configurando uma concorrência predatória. Esta prática diminui as margens de lucro da indústria como um todo e contribui negativamente para a longevidade e saúde das companhias do setor. 
Um dos fatores em discussão por todo o Brasil é a segurança pública. A indústria de transportes é afetada principalmente pelos roubos de carga, sendo o Rio de Janeiro, com mais de 10 mil casos em um ano (2017), o estado com mais ocorrências registradas para estes crimes (Valor Econômico, 2018). Isto gera um aumento em até três vezes dos custos com seguro e consequentemente, o preço do frete de mercadorias já aumentou cerca de 30\% (Gazeta Online, 2018).

\section{Gráfico 2 - Evolução do número de ocorrências de Roubos de Cargas no estado do Rio de Janeiro}

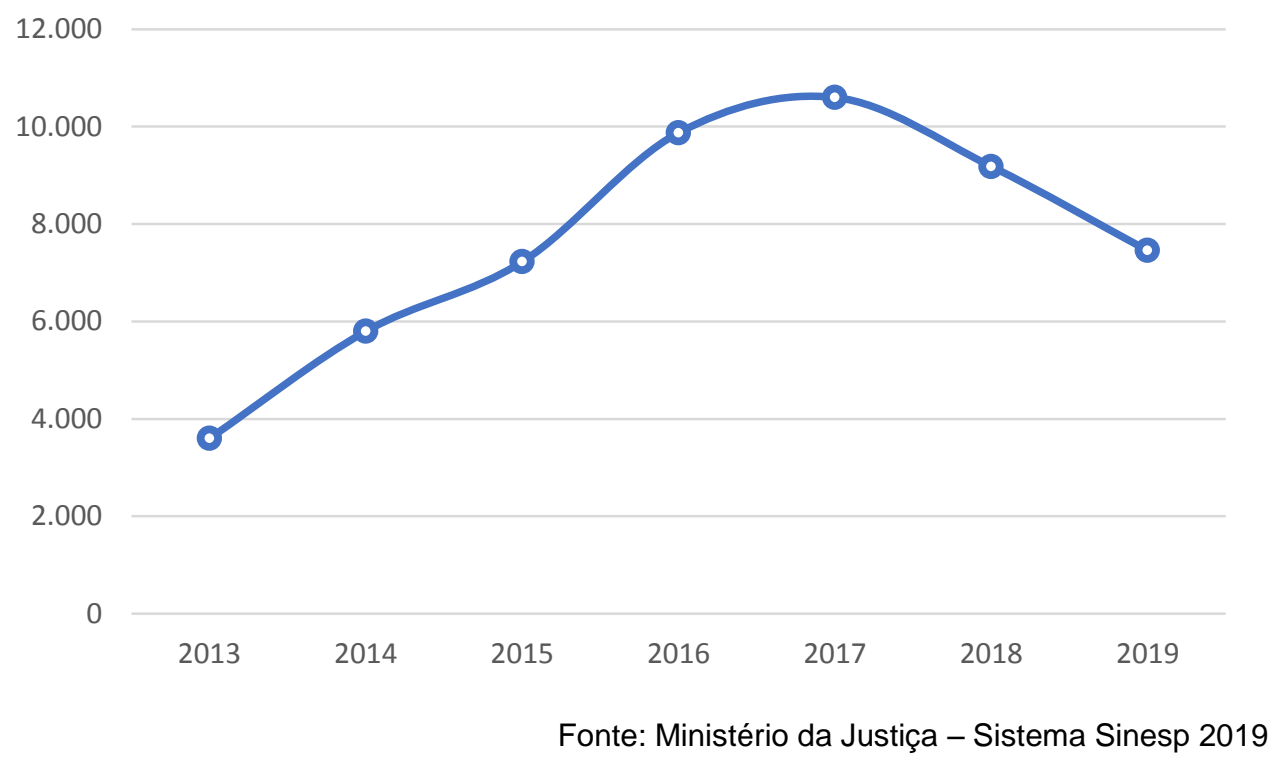

Como a Figura 2 mostra, o pico de ocorrências foi em 2017 e em seguida ocorre uma redução deste índice, de janeiro a maio de 2019 o n de ocorrências foi $21 \%$ menor do que o mesmo período em 2018. O reflexo disto já pôde ser percebido na variação do PIB, enquanto o nacional teve um crescimento (20172018 ) de $1,1 \%$, o do setor de transportes cresceu o dobro, $2,2 \%$, chegando a $R \$$ 256,08 bilhões (CNT, 2018).

Em meio a este cenário, a seguinte questão é levantada:

Quais as principais estratégias que, através de sua adoção no Planejamento Estratégico de uma empresa atuante no transporte de cargas, geram uma vantagem competitiva sustentável? 


\subsection{Objetivo e Delimitação}

O presente artigo busca estudar o mercado brasileiro de transporte de cargas e, a partir disso, descobrir as características e estratégias que gerem vantagem competitiva sustentável para a empresa. Apesar do artigo citar outros modais, este foca no Rodoviário, as conclusões da análise podem ser adaptadas aos outros segmentos do mercado.

O estudo iniciará com entrevistas com diretores, funcionários e clientes de uma empresa atuante no setor em questão e situada no estado do Rio de Janeiro. As conversas seguirão o padrão qualitativo, isto é, uma menor amostra e maior profundidade no assunto abordado, que será entender quais são os principais pontos a serem notados como positivos em uma empresa transportadora de cargas e em seu serviço.

Em seguida, o material produzido nas entrevistas será analisado para entender a cadeia de valor da empresa em questão e identificar características inerentes ao negócio (não apenas as presentes na transportadora em questão, mas sim do segmento como um todo), que por sua vez serão analisadas e classificadas segundo o modelo VRIO.

\subsection{Relevância}

Tendo vivência profissional do setor, entendo que o artigo representa uma forma de recomendação de boas práticas de estratégia e gestão para todas as empresas do setor, contribuindo para a maior profissionalização e o combate a concorrência predatória citada anteriormente.

$\mathrm{Na}$ elaboração deste texto, uma dificuldade foi encontrar artigos, livros e outras obras acadêmicas acerca de pequenas empresas. Nesta lacuna está posicionada esta monografia, trazendo informações e dados consolidados e coletados pelo autor para a academia. Esta obra se coloca também como auxiliar a bibliografia deste tema, podendo ser utilizada como referência para estudos futuros. 


\section{Referencial Teórico}

\subsection{Cinco Forças de Porter}

Publicado pela primeira vez por Michael Porter em um artigo na Harvard Business Review durante o ano de 1979, o modelo é amplamente conhecido e utilizado para a análise do nível de competitividade em uma indústria ou mercado específico.

Figura 1 - Modelo das Cinco Forças de Porter

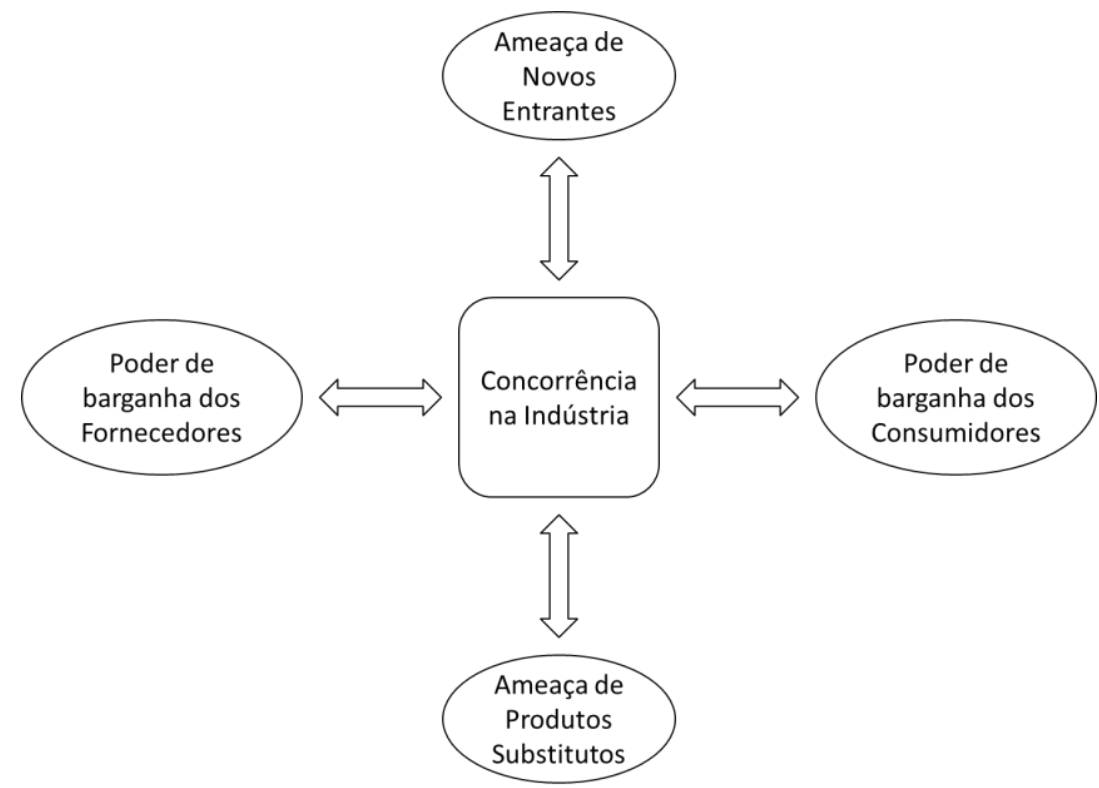

Fonte: Teoria - Porter (2004, p.4)

Visualização - elaborada pelo autor

Seguindo o modelo exibido na figura 3, devem ser analisados os seguintes quesitos: 


\subsubsection{Concorrência na Indústria}

Porter (2004) atribui a rivalidade a uma pressão sentida por um ou mais players de uma indústria ou a percepção de uma oportunidade de crescimento próprio, ainda diz que geralmente a concorrência gera retaliações ou contramedidas visando combater o crescimento do concorrente. Oito fatores são apontados como influenciadores da rivalidade, são eles:

- Crescimento lento da indústria

- Altos custos fixos

- Ausência de diferenciação

- Capacidade aumentada em grandes investimentos
- Concorrentes divergentes

- Grandes interesses estratégicos

- Barreiras de saída elevadas

- Ausência de custos de mudança

Fonte: Porter (2004)

\subsubsection{Poder de Barganha dos Consumidores}

"A escolha de uma companhia quanto aos grupos de compradores a quem vender deve ser vista como uma decisão estratégica crucial" (PORTER, 2004, p.28). Porter faz esta afirmação em seu livro motivado pelo seguinte fato: Os compradores tendem a forçar os preços para baixo e assim, acabam por criar um jogo onde os concorrentes lutam entre si por preço, reduzindo as margens da indústria. Para determinar o poder dos consumidores em um segmento, Porter afirma que devem ser respondidas as seguintes questões:

- Ele está concentrado ou adquire grandes volumes em relação às vendas do vendedor?

- Os produtos que ele adquire da indústria representam uma fração significativa de seus próprios custos ou compras?

- Os produtos que ele compra da indústria são padronizados ou não diferenciados?

- Ele enfrenta poucos custos de mudança

- Ele consegue lucros baixos?

- Compradores que são uma ameaça concreta de integração para trás?

- O produto da indústria não é importante para a qualidade dos produtos ou serviços do comprador?

- O comprador tem total informação? 


\subsubsection{Poder de Barganha dos Fornecedores}

De maneira similar a situação descrita no caso dos consumidores, se forem fortes, os fornecedores poderão reduzir as margens de uma indústria e até mesmo entrar como concorrentes na mesma (integração para a frente). Para Porter (2004), nas seguintes situações os fornecedores são considerados poderosos:

- É dominado por poucas companhias e é mais concentrado do que a indústria para a qual venda

- Não está obrigado a lutar com outros produtos substitutos na venda para a indústria

- A indústria não é um cliente importante para o grupo fornecedor

- O produto dos fornecedores é um insumo importante para o negócio do comprador

- Os produtos do grupo de fornecedores são diferenciados ou o grupo desenvolveu custos de mudança

- O grupo de fornecedores é uma ameaça concreta de integração para frente.

Fonte: Porter (2004)

\subsubsection{Ameaça de Novos Entrantes}

A facilidade com a qual um novo entrante pode surgir em uma indústria determina o grau de estabilidade que ela tem, implicando sobre a rentabilidade do setor. Porter (2004) cita as principais barreiras de entrada de novos concorrentes, que são:

- Economias de escala

- Diferenciação do produto

- Necessidades de capital

- Custos de mudança

- Acesso aos canais de distribuição

- Desvantagens de custo independentes de escala (patentes, acesso a matérias primas, subsídios e curva de aprendizagem).

Fonte: Porter (2004) 


\subsubsection{Ameaça de Produtos Substitutos}

Produtos substitutos são aqueles que são diferentes do seu, porém atingem o mesmo objetivo. Porter (2004) afirma que a simples existência de um produto substituto já impõe um teto aos preços a serem cobrados, reduzindo as margens e lucratividade de uma indústria.

\subsection{Cadeia de Valor}

Para Michael Porter (1989), empresas são compostas por diversas atividades em série que agregam valor ao serviço/produto entregue ao cliente. $O$ autor segmentou em Atividades Primárias - com relação a produção e/ou execução do produto/serviço final - e Atividades de Apoio - oferecem suporte e auxílio a organização sem ter conexão direta com o processo produtivo. Como a Figura 4 mostra, a junção das atividades proporciona a margem e os lucros a serem gerados pela empresa.

Figura 2 - Cadeia de Valor de Porter

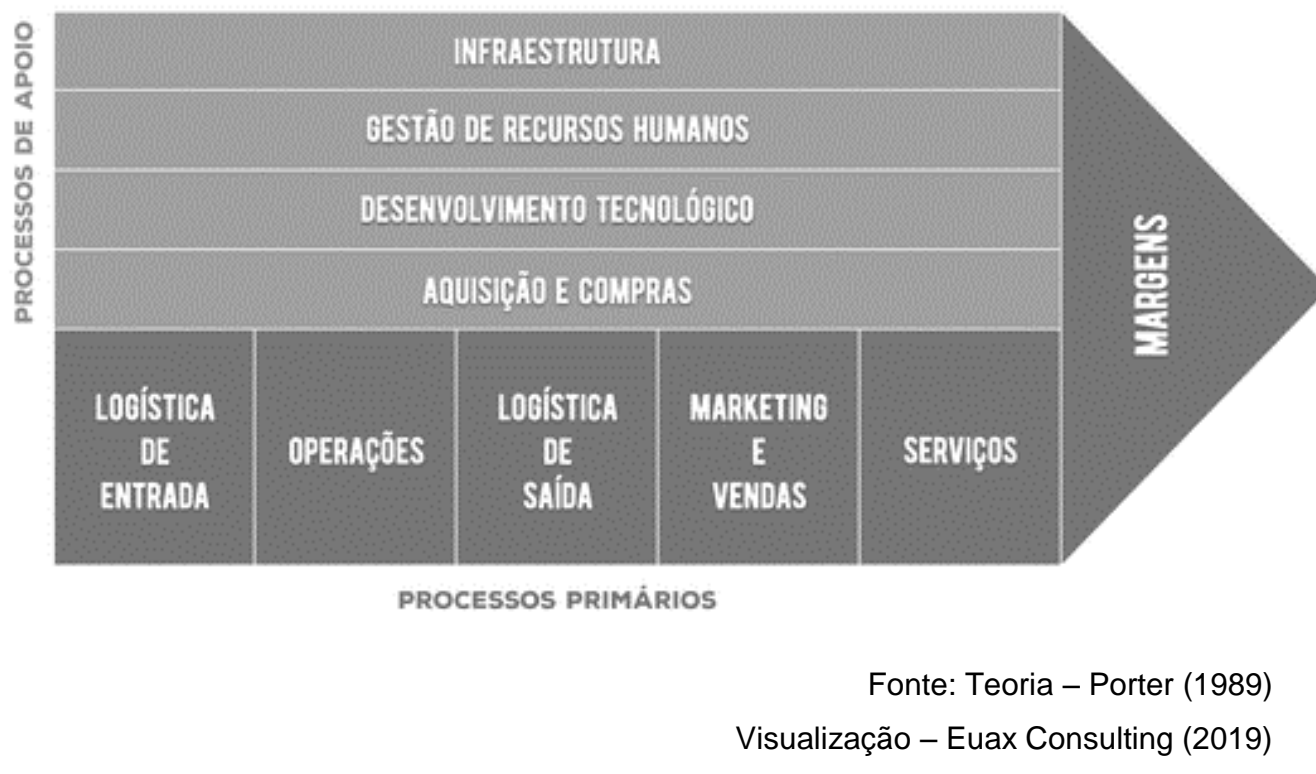




\subsection{Modelo VRIO}

Publicado por Jay Barney inicialmente em 1991 no Journal of Management como um artigo, o modelo era chamado de VRIS - Valor (V), a Raridade (R), a Imitabilidade (I), e a Substituibilidade (S). O modelo compõe o que Barney chama de Visão Baseada em Recursos (VBR) em tradução para o português brasileiro, modelo de gestão que pensa na empresa como consolidadora de recursos financeiros, físicos, humanos e organizacionais (Barney \& Clark, 2007).

Posteriormente, foi revisto por Barney e Clark (2007) e novamente por Barney e Hesterly (2011). Com isso, foi elaborada a atual versão, chamada de VRIO. O propósito do modelo, que é analisar a geração de Vantagem Competitiva por recursos do cenário estratégico empresarial, foi mantido inalterado. A mudança foi uma alteração na composição do modelo, que passou a ser:

\subsubsection{Valor}

Um recurso é considerado valioso quando possibilita a implementação de estratégias que impulsionem a eficiência e eficácia da operação ou quando permite a exploração de oportunidades e minimização de ameaças (Barney \& Hesterly, 2011).

\subsubsection{Raridade}

Recurso raro é aquele que é possuído ou controlado por não muitas empresas no setor e que gere valor a ponto de, possivelmente, ser uma vantagem competitiva. Isto é, não há raridade se não houver valor (Barney, 1991).

\subsubsection{Imitabilidade}

Barney \& Hesterly (2011) dizem que os recursos apenas podem ser considerados vantagens competitivas quando companhias concorrentes enfrentam dificuldades para obtê-los ou desenvolvê-los. Existem três fatores que favorecem a dificuldade de um recurso ser imitado, são eles: Condições únicas de desenvolvimento (impossibilidade de reprodução do percurso); ambiguidade causal (falta de compreensão pela concorrência dos recursos que geram vantagem competitiva); complexidade social (dinâmica interna entre as áreas da companhia) (Barney \& Clark, 2007). 


\subsubsection{Oportunidade}

Ser ou não vantagem competitiva não depende exclusivamente do recurso em si. Resulta também do quanto a organização está preparada para tirar proveito do bem (Barney \& Hesterley, 2011). Barney \& Clark (2007) dizem que, para que o potencial estratégico seja explorado como uma vantagem competitiva, é necessário que haja um alinhamento entre as políticas e procedimentos da empresa ao objetivo final.

Segundo o Modelo VRIO, para que um recurso seja classificado como gerador de vantagem competitiva, é necessário que todos os fatores mencionados anteriormente sejam identificados como existentes no cenário analisado. 


\section{Metodologia}

\subsection{Coleta de dados}

As informações presentes neste artigo foram levantadas por meio da coleta de dados secundários sobre o setor de transportes brasileiro e da realização de entrevistas qualitativas. Este modelo de entrevista não utiliza técnicas estatística uma vez que foca em informações que podem ser consideradas intangíveis, logo não detectáveis por tais métodos, como a dissecação de fatores que levam a uma resposta específica ou então o sentimento do entrevistado sobre algum ponto.

Buscando colher um amplo número de pontos de vista, foram entrevistados diferentes stakeholders de uma transportadora de cargas de pequeno porte e situada no Rio de Janeiro, sendo eles diretores, funcionários ou clientes da mesma. Com o intuito de preservar a segurança de informações possivelmente estratégicas, os nomes dos entrevistados e das empresas em que os mesmos trabalham serão substituídos por alcunhas fictícias. Sendo assim, participaram das entrevistas:

- José - Sócio/Diretor Comercial da Exatidão Express (Transportadora)

- Carlos - Sócio/Diretor Operacional da Exatidão Express (Transportadora)

- Alberto - Coordenador Operacional da Exatidão Express (Transportadora)

- Michel - Coordenador Administrativo da transportadora Exatidão Express

- Luís - Superintendente de Operações da XY Confecções (Indústria Têxtil)

- Roberto - Analista de vendas da AB Embalagens (Indústria de Embalagens)

Apesar de todas as entrevistas compartilharem o propósito de entender sua visão sobre o negócio e as principais características ligadas ao mesmo, a roteirização foi elaborada especificamente para cada um dos grupos de entrevistados. Desta forma, será possível maximizar as informações de cada entrevista. 


\subsection{Tratamento e análise de dados}

Os dados colhidos de fontes secundárias serão utilizados para analisar o setor seguindo o modelo das Cinco Forças de Porter. Os dados colhidos com os profissionais da transportadora serão utilizados para ilustrar a cadeia de valor do negócio, o que fornecerá uma visão clara do funcionamento da empresa.

As informações resultantes das entrevistas também serão utilizadas para listar as principais características e fatores inerentes ao negócio da transportadora em questão. Esta lista será analisada seguindo o modelo VRIO, que nos permitirá diferenciar os fatores que mais importam e também os que pode gerar uma vantagem competitiva para uma empresa do ramo.

\subsection{Limitação do estudo}

Por fazer uso do modelo qualitativo, o presente estudo contará com informações mais ricas em detalhes, porém não terá embasamento estatístico e, por isso, não será possível garantir a certeza dos resultados apresentados se aplicarem para todo o mercado de transportes de cargas.

Por abordar informações e pessoas relacionadas a uma empresa situada no Rio de Janeiro e de porte pequeno, é possível que as análises necessitem ser revistas caso sejam aplicadas a diferentes mercados ou transportadoras que apresentem maior porte ou um posicionamento diferente. 


\section{Apresentação e análise dos resultados}

Este item organizado em 4 seções apresenta e discute os principais resultados alcançados, analisa e discute suas implicações e produz sugestões para que uma transportadora possa se posicionar estrategicamente e se posicionar como uma opção melhor que seus concorrentes.

\subsection{Análise do Setor}

\subsubsection{Concorrência no Setor}

Ao olharmos o segmento nacional de transportes, não conseguimos identificar grandes empresas que dominam o mercado sozinhas. Esta pulverização acontece pelo fato de que o setor é dividido não só no modal de transporte como também pela especialização da empresa no transporte de um tipo de carga específica (medicamentos, cédulas de dinheiro, insumos e muitos outros).

Dentro dos nichos de especialização, a natureza do serviço de transporte cria pouca margem para uma diferenciação entre os concorrentes além da precisão e confiabilidade sobre o serviço prestado. Isto faz com que muitas empresas disputem pelos mesmos clientes, transformando a concorrência em uma competição, que, por consequência da baixa diferenciação, frequentemente se resume ao preço cobrado do cliente.

\subsubsection{Poder de Barganha dos Consumidores}

Pelo produto do ramo ser o serviço de transporte, seus consumidores são as empresas contratantes. É prática comum no setor a realização de contratos de transporte, definindo duração, preços, normas e exigências de ambas as partes. Sendo assim, entende-se que a relação entre uma empresa de transportes e seus clientes tende a ser duradoura e, dependendo do porte das companhias, volumosa em número de viagens.

Se dissecarmos os custos de produção de algum item ou serviço, certamente iremos identificar custos logísticos do mesmo. Isto porque todos os produtos presentes uma prateleira de loja foram transportados para aquele local 
e, antes disso, seus componentes foram levados de diversos lugares diferentes até a fábrica para então este ser produzido.

A representatividade destes custos no preço final varia de acordo com o tipo de item. Os que possuem menor valor agregado tendem a ter uma representatividade maior que os itens mais caros (exemplo: o frete de uma camisa representa percentualmente mais que o frete de um aparelho celular). Apesar disso, itens com maior valor agregado geram mais custos no transporte por demandar maior segurança. Sendo assim, apesar de variáveis de acordo com o objeto a ser transportado, este custo é representativo no preço final de um produto.

Uma linha de produção depende de insumos chegarem até ela e também de seus itens finalizados serem despachados. A logística de transporte é fundamental para garantir a realização e confiabilidade destes inputs e outputs. Sendo assim, é correto afirmar que o serviço oferecido pelas transportadoras é, de maneira geral, de suma importância para seus clientes e seu produto/serviço.

Os contratos envolvendo as transportadoras e seus clientes costumam prever rescisões, quando grandes empresas contratam transportadoras de pequeno ou médio porte, que são a maioria, as barreiras para a quebra de contrato são pequenas. Sendo assim, aliando este fator a forte concorrência por preços abordada no item anterior, vemos uma clientela com um forte poder de barganha sobre os termos do serviço prestado apesar da enorme importância do mesmo para seu funcionamento.

\subsubsection{Poder de Barganha dos Fornecedores}

Os principais fornecedores necessários para o bom funcionamento do serviço de transporte de cargas são os postos/distribuidores de combustível, fabricantes/vendedores de veículos de carga e as companhias seguradoras. Todos os produtos e serviços oferecidos por estes stakeholders são cruciais para a operação visto que se tratam das ferramentas para a prestação do serviço.

Os setores das distribuidoras e dos postos de combustíveis são mais concentrados que o das transportadoras e seu produto é crucial para o serviço de transporte. Em contrapartida, os modelos de negócio são distantes, diminuindo riscos de integração para frene, e o grande volume de combustíveis consumido pelas transportadoras formam grande parte das vendas de 
combustíveis no país. Em 2014, o Diesel (principal combustível utilizado em veículos de carga) representou 40\% do total vendido no Brasil (CNT, 2015).

Existe uma relação de dependência mútua entre transportadoras e produtoras/vendedoras de veículos de carga. Isto por que uma produz e vende a ferramenta utilizada na execução do serviço da outra. O cenário mundial de veículos de carga é dividido pelos modais de transporte, mas dentro destes nichos há uma concorrência dentro de cada um. No modal rodoviário, por exemplo, as principais marcas são: Volvo, Volkswagen, Scania, Mercedes, Ford e Iveco.

No Brasil, a segurança pública é uma questão a ser considerada em qualquer segmento de negócios. No ramo de transportes, essa questão exige uma preocupação ainda maior devido à grande incidência de roubo de cargas, principalmente no estado do Rio de Janeiro. Esta situação gera a necessidade da contratação seguros para as cargas transportadas. Os entrevistados mencionaram que é prática comum do mercado apenas contratar serviços com seguro e que os custos com isto chegam a representar $2 \%$ do valor de nota da carga transportada.

Como maneira de estender seus serviços, transportadoras rodoviárias, ocasionalmente subcontratam empresas que operam em outro modal. Podemos identificar esta situação no caso de uma transportadora rodoviária contratar uma companhia aérea para atender a alguma demanda urgente. Nestas situações, os principais fornecedores no mercado brasileiro são: LATAM Airlines Brasil, Gol Linhas Aéreas e Azul Linhas Aéreas. Apesar de disputarem entre si principalmente através da tarifa cobrada, a demanda pelo serviço oferecido por estas companhias costuma ser maior que a oferta do mesmo. Além disto, os custos de uma empresa atuante no modal aéreo geralmente possuem lastros em dólar, podendo oscilar repentinamente e levar os preços praticados pelas companhias consigo.

Um insumo importante para o serviço de transporte rodoviário é o óleo Diesel utilizado pelos veículos. No brasil, a distribuição de combustíveis é monopolizada pela Petrobras, companhia que tem como principal acionista o governo brasileiro. A empresa foi utilizada no passado como ferramenta de controle do preço de combustíveis no país.

Após uma série de descobertas de incidentes envolvendo corrupção na instituição pela operação Lava-Jato entre 2014 e 2016, a diretoria da Petrobras comunicou que os preços passariam a seguir interesses da empresa e padrões do mercado, sem haver qualquer interferência do governo federal brasileiro. A 
seguinte imagem mostra a realidade de aumentos progressivos no preço do combustível desde então:

\section{Gráfico 3 - Preço do Litro de Óleo Diesel}

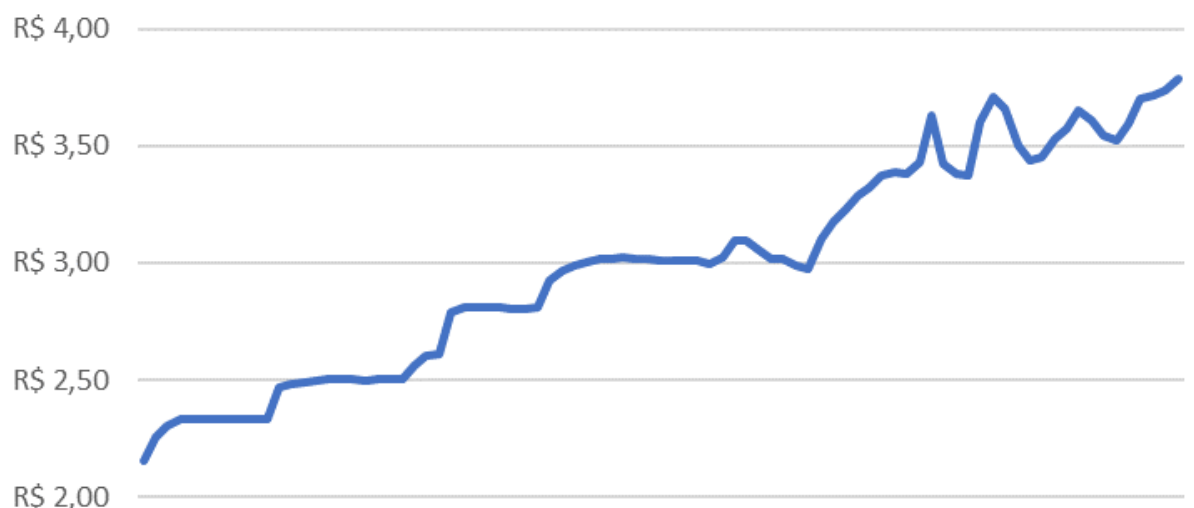

$\mathrm{R} \$ 1,50$

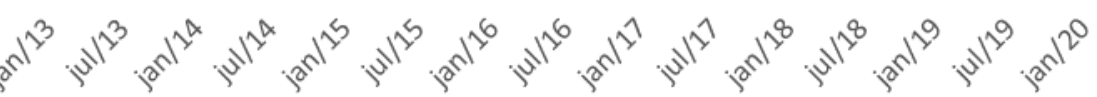

Fonte: Agência Nacional do Petróleo, Gás Natural e Biocombustíveis (ANP),2020

Por não haver empresas ou produtos alternativos ao combustível fóssil, as distribuidoras deste possuem um forte poder de barganha com as transportadoras. As companhias aéreas também ocupam uma posição similar como fornecedoras de seus serviços, porém não possuem poder de barganha considerável como fornecedor para transportadoras de cargas rodoviárias pois são uma alternativa ao serviço principal oferecido pela empresa. Já produtoras de veículos e seguradoras, por atuarem em um mercado mais pulverizado, também não possuem um forte poder de barganha.

\subsubsection{Ameaça de Novos Entrantes}

O processo de iniciar uma companhia de transporte de cargas e as regulamentações envolvidas variam de acordo com cada modal. No rodoviário, existem regras de funcionamento e também exigências de seguradoras e dos clientes, mas não há nenhum tipo de restrição para novas empresas. Isto significa que, a qualquer momento, alguma companhia pode surgir e assumir clientes de empresas antigas.

A baixa diferenciação presente nos segmentos da indústria dos transportes e a facilitação de acesso ao capital através de financiamentos ou afins também são fatores que podem favorecer novos entrantes no setor. A inovação através 
de novos métodos ou sistemas patenteados pode se tornar um diferencial e dificultar o progresso de novas empresas.

\subsubsection{Ameaça de Produtos Substitutos}

A principal ameaça de substituição em uma operação logística de transporte, é esta ser substituída por uma paralela, porém utilizando outro modal. Isto é, uma empresa que trabalha com transporte rodoviário passa a atender um cliente que antes utilizava o modal aéreo devido aos menores custos. O item 1.1 conta com uma descrição de cada modal e suas vantagens e desvantagens.

A enorme demanda por transporte de itens (produtos finais ou insumos) em diversos setores da economia faz com que o serviço de transporte seja imprescindível. Apesar disso, inovações tecnológicas e dos meios de produção podem vir a diminuir esta necessidade ou até mesmo criar novas maneiras de realizar este serviço.

\subsection{Cadeia de Valor do negócio}

Utilizando informações coletadas nas entrevistas com gestores, funcionários e clientes e também conhecimentos prévios do autor sobre a transportadora em questão, a operação da companhia foi desenhada da seguinte maneira:

\subsubsection{Processos de Apoio}

\subsubsection{Infraestrutura}

Devido à natureza do serviço prestado, uma empresa do ramo de transportes necessita de alguns recursos para seu funcionamento. No caso da transportadora Exatidão Express, são eles:

\subsection{Frota de veículos}

A empresa conta com um total de 16 veículos, sendo eles: 1 Caminhonete pequena, 1 veículo de passeio, 1 van, 2 furgões, 4 caminhões "leves" (baú de $x_{x m^{2}}$ ), 4 caminhões médios (baú de $x^{2} m^{2}$ ) e 3 caminhões pesados (baú de $\left.x \times m^{2}\right)$.

A detenção de uma frota própria é um fator que entrega a empresa mobilidade e autonomia em sua operação na contrapartida de gerar custos de 
manutenção com os veículos, que são mitigados com reparos preventivos e pelo fato de a empresa apenas adquirir veículos novos e continuamente substituir veículos antigos.

\subsubsection{Terminal de cargas}

Uma transportadora necessita de um espaço onde possa descarregar, tratar/separar, carregar e eventualmente armazenar cargas de seus clientes. Além disto, o espaço pode ser usado com estacionamento para os veículos que não estiverem em viagem no momento. É importante que este terminal de cargas seja de dimensões e capacidade compatíveis com a operação e veículos da transportadora.

A companhia Exatidão Express possui 01 galpão no bairro de Bonsucesso, Rio de Janeiro, que é utilizado como terminal de carga principal e escritório administrativo. A empresa também aluga um outro galpão menor no mesmo bairro, que é usado como terminal de carga secundário e também como estacionamento para veículos que não são comportados pelo terminal principal.

Durante as entrevistas, foi mencionado por um dos funcionários da empresa que um dos empecilhos para o crescimento da empresa é justamente o tamanho de seus terminais de carga. Os sócios também consideram este ponto um gargalo para a companhia e, por isso, existem planos de migração para um espaço mais amplo e adequado.

\subsubsection{Gestão de Pessoal}

No momento em que este estudo foi realizado, a transportadora contava com aproximadamente 23 colaboradores, sendo 7 ajudantes de transportes, 8 motoristas, 4 auxiliares administrativos, 2 jovens aprendizes e 2 sócios que também atuam como diretores.

Esta área foi apontada pelo entrevistado Alberto, como, em sua opinião, o principal desafio do setor. Tendo passado por diversas transportadoras em cargos de supervisor de operações, este funcionário reportou situações onde problemas pessoais de um empregado específico impactou negativamente o desempenho de toda a equipe e gerou problemas para a companhia.

\subsubsection{Gestão Administrativa Financeira}

Tendo como principal objetivo o auxílio e a manutenção ao bom andamento não só da operação, mas do negócio como um todo, esta área de 
gestão pode ser dividida em: Setor Administrativo, que é responsável pela organização e dos insumos e ferramentas necessárias para a realização das demais áreas e atividades do negócio; Setor Financeiro, que engloba procedimentos relacionados a movimentação e controle das finanças da empresa, como contas a pagar e a receber, controle de cobrança e de caixa entre outros.

\subsubsection{Processos Primários}

\subsubsection{Atendimento Comercial e Vendas}

$\mathrm{Na}$ empresa, a área comercial é subdividida em: Serviço de Atendimento ao Cliente (SAC), que é maior ponte de contato entre o contratante e a contratada, sendo responsável principalmente por notificar as empresas contratantes sobre a situação e andamento do serviço; Vendas, área que é gerida diretamente pelo sócio José e composta por uma pessoa jurídica (PJ), que presta serviços de representação comercial para alcançar novos clientes.

Desde sua criação, a empresa foi voltada a atender serviços de emergência, tendo como principal característica a agilidade e confiabilidade no transporte. Até hoje, vende-se um serviço de excelência aos clientes. Por isso, em todos os pontos seguintes, os sócios e funcionários descreveram a tolerância com erros como inexistente.

\subsubsection{Processos de Coletas}

Uma vez contratada para realizar um serviço de transporte, a companhia necessita recolher a carga no lugar indicado pelo cliente. Este é o momento onde o objeto da entrega é passado do contratante para a transportadora, sendo necessária a emissão de documentos como notas fiscais de transferências e Conhecimento de Transporte Eletrônico (CTE).

\subsubsection{Tratamento de Cargas}

Em alguns casos, a prestação do serviço é estendida para além do transporte de cargas, podendo adicionar atividades como por exemplo agrupamento de produtos em kits, separação da carga coletada de acordo com algum critério ou algum outro tipo de tratamento solicitado. Estas tarefas podem acontecer ou não de acordo com a necessidade do cliente e o serviço contratado. 


\subsubsection{Viagens e Transferências}

O serviço vendido pela transportadora Exatidão Express é o de transporte aéreo e rodoviário, variando de acordo com as necessidades do cliente. No primeiro, a companhia utiliza companhias aéreas como LATAM Airlines Brasil, Gol Linhas Aéreas e Azul Linhas Aéreas Brasileiras para realizar o transporte em seus aviões, o que agrega escalabilidade e velocidade ao processo. Parcerias com as cias aéreas possibilitam tarifas inferiores as praticadas no mercado, diminuindo o preço final pago pelo.

Já as viagens rodoviárias, são realizadas com frota e funcionários próprios da empresa. A manutenção preventiva e utilização apenas de veículos em bom estado minimizam a possibilidade de ocorrer algum problema durante 0 transporte. Por este modal utilizar caminhões, os custos com transporte ou transferência de carga são reduzidos. Em contrapartida, o tempo de entrega tende a aumentar. Através de técnicas de planejamento de envios, a companhia Exatidão Express é capaz de praticar preços de modal rodoviário ainda minimizando seu tempo de entrega.

É importante mencionar que todas as viagens realizadas pela empresa em qualquer modal seguem protocolos de segurança estabelecidos por companhias seguradoras e gerenciadoras de riscos, mitigando o impacto da situação precária de segurança pública no estado e no país mencionada no tópico 1.1 .

\subsubsection{Processos de Entrega}

Após o transporte passar a fase de viagem, é necessário que a carga chegue ao seu destinatário final, este pode ser o cliente final da contratante, um centro de distribuição local da mesma, um representante comercial ou qualquer outro ponto de escolha do cliente.

Nas operações onde a transportadora atua através de companhias aéreas, a empresa contratante é responsável por disponibilizar um operador para executar a parte final do serviço de transporte. Durante as entrevistas, os sócios mencionaram que costumavam assumir a entrega final no modal aéreo e o faziam através de subcontratações. Por problemas com o controle de qualidade e confiabilidade do serviço na parte que a Exatidão não tinha controle, foi decidido não mais proceder desta maneira.

Já no modal rodoviário, a transportadora Exatidão Express costuma realizar as entregas finais por si. Desta forma, a empresa consegue prover 
garantias ao seu cliente quanto a qualidade do serviço prestado desde seu início até o encerramento do mesmo.

\subsubsection{Margens}

Todas as atividades e informações apresentadas anteriormente neste item existem e contribuem de maneira sinérgica para que a empresa consiga cobrar, além dos custos tidos com sua operação, uma margem de lucro em cima do serviço prestado. Durante a entrevista com Carlos, sócio da empresa, o mesmo afirmou: "Quanto maior a complexidade e necessidade do serviço prestado, maiores serão as margens de lucro."

Ao agregar os tópicos anteriores, a visualização da cadeia de valor da empresa apresentou-se da seguinte maneira:

\section{Figura 3 - Cadeia de Valor da transportadora Exatidão Express}

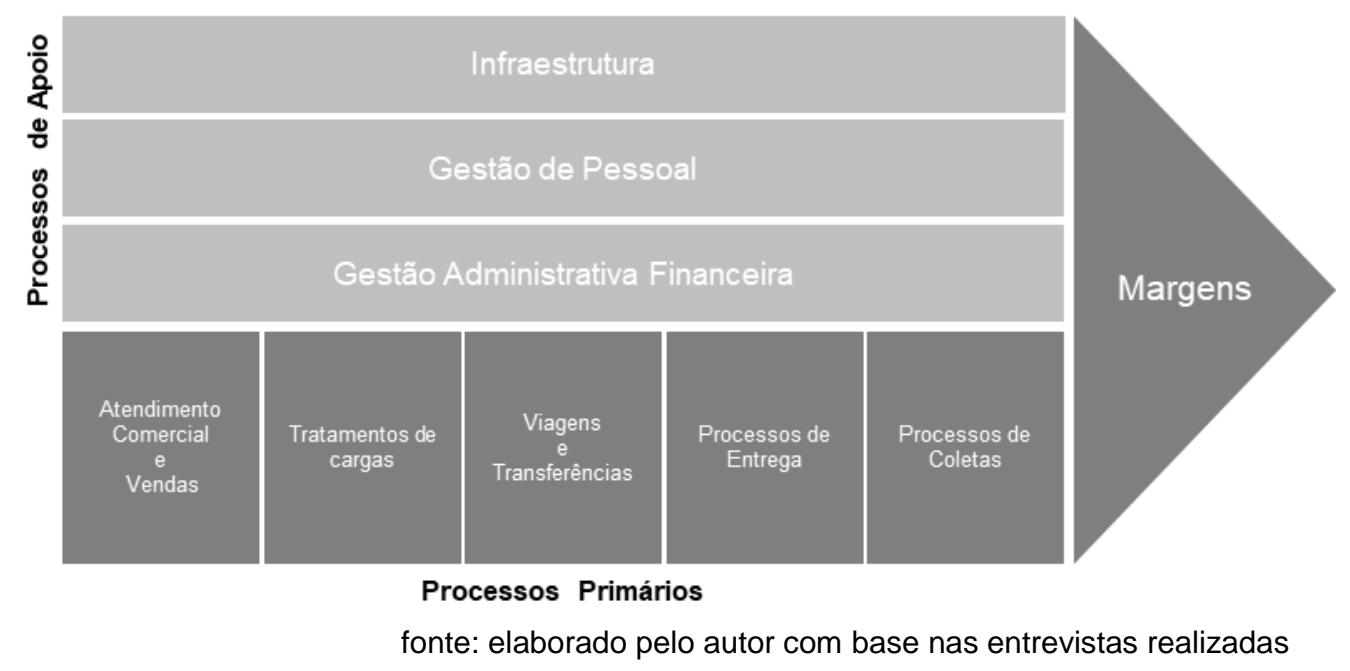

\subsection{Análise VRIO}

\subsubsection{Adaptabilidade ao cliente}

Empresas de diferentes ramos possuem peculiaridades em sua produção, armazenamento e também quanto ao transporte de seus produtos. É importante que o serviço de transporte tenha a capacidade de se adaptar à realidade e situação de cada cliente para melhor atendê-lo.

Em situações onde a transportadora não se adapta para atender a um contratante, o processo inverso é necessário para que as operações se encaixem, gerando custos de mudança para o cliente e, temporariamente, atrapalhando a eficiência de sua operação. Por destacar o serviço de transporte 
em meio a concorrentes, a característica de adaptabilidade gera valor para a empresa.

Durante as entrevistas, Carlos, sócio da companhia Exatidão Express, descreveu transportadoras grandes como "elefantes", tendo pouca agilidade devido ao tamanho de sua estrutura. O empresário destacou que, apesar de pequenas e médias empresas não conseguirem atender na mesma escala que as maiores, a operação destas tende a ser mais maleável e adaptável. Tendo em vista o fato de que porte este recurso é comum entre as transportadoras de médio e pequeno, não há raridade no mesmo.

O principal gerador da rigidez que leva transportadoras a serem menos adaptáveis é o aumento da complexidade da estrutura da empresa. A conciliação entre o crescimento da companhia e a manutenção de sua operação como adaptável aos clientes é um desafio para o setor. Apesar disso, esta adaptabilidade é natural entre companhias com estruturas enxutas. Por isso, o recurso é considerado de fácil Imitabilidade.

Um dos atributos do serviço de transporte vendido pela Exatidão Express é justamente a possibilidade de o cliente moldar a operação de coleta, transporte e entrega de acordo com sua necessidade, mostrando que a companhia está organizada para a oportunidade de se beneficiar deste recurso.

\subsubsection{Confiabilidade do serviço}

Entende-se como confiabilidade o nível de fidelidade da informação passada no discurso de vendas e acompanhamento do transporte de cargas em relação a realidade. No contexto da Exatidão Express, isto se reflete no quanto os prazos passados aos clientes são cumpridos e ao quão confiável as informações passadas pela companhia são. A veracidade e precisão destas informações são de suma importância pois é baseado nelas que o cliente planeja próximas etapas de sua operação.

A integração da confiabilidade como um recurso do serviço vendido pela empresa gera uma oportunidade de atender nichos de mercado que dependem disto e, através desta especialização, é possível se tornar líder do serviço dentro deste nicho. Além disto, ao levar a confiabilidade como prática na operação, a eficácia da empresa se torna seu principal diferencial, fazendo com que este recurso gere valor para a empresa

Luís e Roberto, clientes da transportadora Exatidão Express que tem contato direto com a serviços de outras transportadoras em outras áreas 
funcionais de suas empresas, reconheceram que o nível de competência e qualidade praticado no serviço da Exatidão Express é diferenciado dos demais concorrentes e incomum no mercado, sendo então um recurso raro.

O serviço prestado pela empresa é de difícil Imitabilidade não devido a algum tipo de limitação física ou financeira, mas sim pelo fato de foi elaborado e possibilitado pela experiência dos profissionais envolvidos, principalmente dos gestores, que já trabalham no mercado de transportes a mais de 30 anos.

Durante a entrevista, Luís disse: "Para mim, é ruim que a carga chegue antes do prazo combinado e nem depois". Isto nos mostra que o serviço contratado pela empresa do entrevistado requer um elevado nível de precisão. Este nível de comprometimento e acurácia também foi apontado por todos os colaboradores entrevistados como a principal força da companhia, isto nos mostra que como a mesma está preparada e utiliza este recurso de maneira estratégica para se destacar no mercado.

\subsubsection{Tecnologia da informação}

O uso mais comum de tecnologia da informação no mercado de transportes é no acompanhamento de envios. O sócio Carlos, em sua entrevista, mencionou o seguinte: "Toda empresa de carga em que eu trabalhei pecava pela informação. Não basta entregar, temos que informar os clientes de que foi entregue". É importante ressaltar que existem inúmeras outras aplicações neste setor, como a previsão de probabilidades de eventos indesejados durante viagens, controle de manutenção e viagens de veículos, entregas com veículos autônomos entre outros.

A presença de tecnologia inserida nos processos de qualquer empresa tem a capacidade de impulsionar a eficiência e eficácia através de redução de tempos de execução ou eliminação de etapas não necessárias para a operação. Desta forma, o recurso agrega valor à companhia.

A primeira utilização de rastreamento de envios foi em 1994 pela FedEx, que se tornou uma das maiores transportadoras do mundo com um volume anual de 3 bilhões de pacotes entregues em 2018. Pelos quase trinta anos de sua primeira utilização, diferentes empresas ao redor do mundo já empregam esta tecnologia em sua operação, fazendo com que a mesma não tenha raridade. Entretanto, de acordo com a complexidade da tecnologia empregada em outras soluções, a raridade tende a aumentar. 
Aplicações tecnológicas de desenvolvimento interno em empresas costumam ser patenteadas e protegidas contra cópias, impossibilitando um concorrente de replicar o recurso em sua total complexidade. Em casos onde a aplicação é no formato de um serviço contratado, as mesmas restrições quanto a cópia e patentes se aplicam, porém há a possibilidade de contratação de um serviço parelho ao do concorrente. Tendo em vista que mesmo no cenário da possível contratação do serviço, isto seria custoso, o recurso é de difícil Imitabilidade.

A companhia Exatidão Express utiliza a tecnologia da informação apenas de maneiras básicas, como planilhas de controle de quilometragem de frota ou controle de férias de funcionários. A empresa utiliza um sistema próprio para companhias do ramo, que tem a capacidade de gerar análises comparativas de governança, lucros, custos além de fornecer uma visão $360^{\circ}$ da operação de transporte. Entretanto, o software é utilizado apenas para operações básicas como realizar faturamentos e emissão de notas fiscais. Não existe na companhia nenhum tipo de acompanhamento automatizado dos envios, sendo necessária a passagem de informação manualmente dos motoristas ou entregadores para os clientes da empresa. Sendo assim, a empresa não está preparada para utilizar de maneira estratégica as oportunidades geradas pela tecnologia.

\subsubsection{Infraestrutura própria}

Independendo do modal, o mercado de transporte de cargas requer meios de levar objetos do ponto de origem até o destino e também locais de armazenamento deste produto e do próprio meio de transporte durante o tempo em que o mesmo não é utilizado.

O fato de uma companhia ser proprietária de sua frota gera autonomia para a mesma tomar decisões e manejar seus veículos da maneira que julgar necessária além de não gerar custos financeiros adicionais com os mesmos. Já em relação a detenção do espaço físico utilizado pela empresa como armazém ou estacionamento, apesar de, assim como os veículos, evitar custos financeiros anuais para a empresa, o crescimento da operação pode fazer este recurso se tronar uma limitação para o progresso da empresa. Conclui-se que a detenção própria da frota de veículos contribui para a operação da empresa enquanto a posse da infraestrutura não agrega valor.

Em relação a frota, Apesar de muitas transportadoras operarem subcontratando caminhoneiros independentes, a detenção de veículos por 
empresas de transporte é prática comum no setor. Por não gerar valor para a empresa, a propriedade do espaço físico não agrega valor e consequentemente, o recurso não pode ser considerado raro.

A propriedade da infraestrutura é inegavelmente custosa a empresa, o valor de mercado da frota de caminhões da Exatidão Express supera os $R \$ 1,5$ milhão (um milhão e 500 mil reais) e dos galpões utilizados pela operação alcança os $R \$ 1,8$ milhão, sendo aproximadamente $R \$ 1,2$ milhão do galpão próprio e $\mathrm{R} \$ 600$ mil da instalação alugada. Isto faz com que este fator seja de difícil Imitabilidade.

A frota da companhia é a principal ferramenta utilizada nas operações de coleta, viagens, transferências e entregas ao longo das rotas programadas. A utilização dos veículos se dá de acordo com a necessidade de cada serviço e a manutenção é realizada de acordo com as recomendações do fabricante de cada veículo. Não foi identificado qualquer tipo de utilização estratégica da frota.

Os sócios Carlos e José compartilharam nas entrevistas um dilema que a empresa sofre quanto a sua infraestrutura, é proprietária da principal instalação que utiliza, mas esta já não comporta a operação de maneira confortável, decorrendo na necessidade de retrabalhos e impedindo o bom andamento da companhia. O tipo de instalação necessário para este modelo de negócio costuma ser situado em condomínios empresariais, que, geralmente, não são vendidos e sim alugados. Cotações realizadas pelos sócios indicam que o gasto com aluguel de um espaço adequado seria em torno de $\mathrm{R} \$ 240$ mil (duzentos e quarenta mil reais) ao ano além dos custos com obras. Devido à falta de contribuição estratégica para a operação, a empresa não está preparada para aproveitar a oportunidade gerada pelo recurso.

\subsubsection{Instrumentos de segurança}

A situação da segurança pública no Brasil, descrita no item 1.1, exige que contrapartidas sejam tomadas com o intuito de prevenir incidentes com cargas em transporte e também de garantir ao cliente que, no evento de um sinistro envolvendo sua carga, este não será lesado. O principal item de segurança é o seguro de veículo e de carga transportada, que, por sua vez, pode exigir uma série de subitens dependendo da natureza do transporte, como por exemplo: Rastreamento de veículos em tempo real, Bloqueador de veículos, escoltas armadas, iscas rastreadas inseridas na carga entre outros. 
Além de atuar de maneira reativa a situações como roubos de carga e similares, os instrumentos de segurança supracitados minimizam as chances de acontecer algum evento desta natureza uma vez que dificulta a ação, diminuindo a atratividade daquele veículo específico. Por isso, este recurso agrega valor ao serviço de transporte oferecido pela Exatidão Express.

Por se tratar de itens exigidos pelos contratantes e seguradoras, é comum no mercado que transportadoras apliquem tais itens em seu serviço, fazendo com que o recurso não possua raridade no mercado.

O mercado das seguradoras e dos fornecedores dos subitens requeridos por ela não pratica nenhum tipo de restrição ou exclusividade e, por isso, não há qualquer barreira para a imitação deste recurso além dos custos envolvidos em obtê-los.

A companhia Exatidão Express opera de acordo com as exigências de sua seguradora, seguindo processos recomendados pela mesma e utilizando todos os itens de segurança requeridos de acordo com cada transporte. A companhia está estabelecida de maneira a utilizar este recurso para garantir a segurança para seus colaboradores e também para o contratante de seus serviços.

\subsubsection{Preço}

Os entrevistados, em unanimidade, destacaram o fator preço ao serem questionados a respeito da concorrência. Michel falou sobre o processo de precificação de empresas concorrentes: "outras companhias não levam em consideração na elaboração de seu preço itens como custos com itens de segurança, impostos, renovação e manutenção de frota." Além disso, José acrescentou: "Existem clientes que incentivam esta prática, escolhendo empresas baseados apenas no preço. É comum disputar com um concorrente e após 6 meses ou 1 ano descobrir que esta mesma transportadora está falindo." Será analisado como recurso neste tópico o preço e o processo de elaboração do mesmo na Exatidão Express.

É prática corrente na empresa realizar sua precificação levando em conta todos os fatores mencionados no parágrafo anterior pois apenas desta maneira, é possível garantir ao cliente a execução do serviço mantendo a qualidade, saúde e melhoria contínua da operação. Apesar disso, o distanciamento do preço praticado pela empresa em relação ao do mercado gera questionamentos e insatisfação dos clientes atuais além de uma barreira para a contratação e renovação de contrato com a empresa. Sendo assim, o preço praticado pela 
Exatidão Express possui valor no cenário da empresa, mas precisa ser continuamente revisto com o intuito de minimizar a ameaça gerada pelo seu aumento.

A realidade descrita pelos entrevistados quanto a concorrência predatória baseada na disputa por preço é provocada por algumas empresas no ramo que, por praticarem precificações não racionais, acabam por impactar negativamente as margens praticadas por todo o setor. Sendo assim, praticar preços elaborados nos fatores supracitados não é um recurso raro.

Existe uma dificuldade na compreensão pelo mercado das transportadoras de como a disputa através do preço pode prejudicar todas as empresas do ramo. Isto é um dos fatores que "ecoa" a competição predatória no setor. A construção de uma precificação adequada não é custosa, basta levar em consideração todos os valores gastos para a execução do serviço sem comprometer a qualidade do mesmo. Por isso, este recurso é de fácil Imitabilidade

Para que os valores adicionais levados em conta no processo de precificação gerem benefícios para a companhia, é necessário que estes sejam devidamente mensurados e executados. Exemplo disso é a renovação e manutenção de frota. Para que uma transportadora consiga operar sem problemas com veículos, é importante que esta utilize seu capital para manutenção do mesmo e substituí-lo ou renová-lo quando necessário. Tendo em vista o cenário da transportadora Exatidão Express, é correto afirmar que a mesma está organizada para tirar proveito da oportunidade gerada por este recurso.

\subsubsection{Identidade empresarial}

O sócio e diretor comercial José apontou como o principal desafio do setor a empresa se encontrar dentro mercado, como dito por ele: "Saber a quais nichos atender e de que maneira o fazer". Além de conhecer o posicionamento, os colaboradores da companhia devem exercita-lo na operação. A Exatidão Express busca atender principalmente companhias que precisam de altos níveis de agilidade e confiabilidade em sua operação.

O recurso pode gerar valor na tomada de decisões estratégicas, onde os tomadores de decisão terem conhecimento da identidade empresarial pode ser um fator facilitador uma vez que sabendo o conceito que uma empresa representa, basta optar pela alternativa mais próxima a este. Além disso, uma 
empresa com sua "personalidade" definida é capaz de crescer ordenada e controladamente, maximizando a longevidade da companhia.

Os entrevistados, que possuem experiência no mercado de transporte de cargas, relataram que é comum que transportadoras de pequeno e médio porte existam e operem sem que os colaboradores e nem os diretores conheçam e pratiquem a identidade da mesma, enfraquecendo a marca. Sendo assim, podemos afirmar que este recurso possui raridade.

Assim como a identidade de indivíduos, a identidade empresarial é complexa pois existe uma história própria por detrás de cada uma. Por isso, é de grande dificuldade a clonagem de uma empresa. Entretanto, cada empresa pode estudar o mercado de maneira a entender como deve se situar e, a partir disto, construir sua própria identidade. Principalmente pela individualidade de profissionais, recursos e histórico envolvidos na identidade empresarial, o recurso é de difícil Imitabilidade.

Todo o discurso de vendas utilizado pela Exatidão Express gira em torno da identidade empresarial construída ao longo de seus 17 anos de existência. Além disto, a operação da empresa foi elaborada para ir ao encontro da identidade. Por isso, podemos afirmar que a companhia está organizada de maneira a tirar o máximo proveito deste recurso tanto em seu discurso de vendas quanto na execução de sua operação.

Tendo em vista os dados apresentados nos tópicos anteriores, foi elaborada uma tabela onde se tem uma visão resumida das informações:

Tabela 1 - Resumo do resultado da Análise VRIO

\begin{tabular}{|c|c|c|c|c|c|}
\cline { 2 - 5 } \multicolumn{1}{c|}{} & Valor & Raridade & Imitabilidade & Oportunidade & Conclusão \\
\hline Adaptabilidade ao cliente & $\checkmark$ & $X$ & $X$ & $\checkmark$ & Não Gera VC \\
\hline Confiabilidade do serviço & $\checkmark$ & $\checkmark$ & $\checkmark$ & $\checkmark$ & Gera VC Sust. \\
\hline Tecnologia da informação & $\checkmark$ & $X$ & $\checkmark$ & $X$ & Não Gera VC \\
\hline Infraestrutura própria & $X$ & $X$ & $X$ & $\checkmark$ & Não Gera VC \\
\hline Instrumentos de segurança & $\checkmark$ & $X$ & $X$ & $\checkmark$ & Não Gera VC \\
\hline Preço & $\checkmark$ & $X$ & $\checkmark$ & $\checkmark$ & Gera VC Sust. \\
\hline Identidade empresarial & $\checkmark$ & $\checkmark$ & & $\checkmark$ & $\checkmark$ \\
\hline
\end{tabular}




\section{Conclusão}

Com o intuito de compreender o mercado das transportadoras de cargas rodoviárias, foi realizado uma análise setorial baseada no modelo de Michael Porter (2004). Foi percebido que o segmento é conhecido por possuir grandes companhias atuando sem dominar o mercado completamente para si, tornando o setor pulverizado, o que potencializa a concorrência entre as empresas que o compõe. A natureza simples do serviço prestado pelas transportadoras restringe a possibilidade de diferenciação. Entretanto, é possível identificar que algumas empresas conseguem se destacar através da especialização de atendimento para certos nichos.

A grande concorrência no setor faz com que contratantes do serviço de transportes detenham forte poder de barganha em relações com transportadoras. Já os fornecedores de insumos ou serviços utilizados no transporte rodoviário, no geral, possuem pouco poder de barganha pelo fato de também atuarem em um mercado pulverizado ou então serem substituíveis. 0 único fornecedor que escapa desta regra são os distribuidores e produtores de combustíveis, isto acontece por atuarem em um mercado monopolizado que vende um insumo vital para a execução do serviço de transporte.

Foi identificado que não existem restrições legais ou qualquer impeditivo a novos entrantes no mercado além de exigências e tributos locais envolvidos no negócio. Entretanto, uma possível dificuldade a ser enfrentada é a iniciação de relacionamentos em um mercado onde seus concorrentes atuam a mais tempo. Além disto, notou-se que, a demanda logística gerada pelo ciclo de consumo global, torna o serviço de transporte em si, insubstituível. Ainda assim, o modal rodoviário pode ser substituído por algum outro de acordo com as necessidades do cliente.

Buscando ir mais a fundo no mercado, foram realizadas entrevistas qualitativas com funcionários e clientes de uma transportadora de pequeno porte situada no Rio de Janeiro e que atua no modal rodoviário, esta é chamada de Exatidão Express. As informações foram então utilizadas para elaborar uma visualização gráfica da empresa seguindo o modelo da Cadeia de Valor de Michael Porter (1989). Não apenas foram estudados os processos primários e 
secundários como também a forma com que, a junção destes sustenta as margens do negócio.

As entrevistas realizadas serviram como fonte de dados também para uma listagem das principais características da operação da Exatidão Express. Esta lista foi então analisada segundo o Modelo VRIO, que permitiu uma dissecação dos recursos da empresa e a compreensão não apenas de se os fatores geram ou não uma vantagem competitiva sustentável como também se estes possuem o potencial para tal e, por alguma razão, não são aproveitados.

Apesar de não ter potencial de gerar vantagem competitiva para a empresa, vimos que a adaptabilidade é um recurso de destaque em pequenas e médias empresas visto que a mesma garante que o cliente terá um esforço mínimo ao utilizar seu serviço. Já a confiabilidade, é fator chave para a manutenção do relacionamento entre o contratante e a transportadora e para a entrega de um serviço de qualidade, podendo gerar uma vantagem competitiva sustentável principalmente pela sua diferenciação no mercado. É importante ressaltar que a adaptabilidade ao cliente aliada a confiabilidade no serviço permite que a transportadora se posicione em nichos de mercado onde a importância de seu serviço é maior na operação de seu contratante, aumentando seu poder de barganha em detrimento do poder do cliente.

O artigo ressaltou a importância da tecnologia da informação no negócio e o potencial deste recurso para melhorar processos e gerar destaque no serviço prestado em uma empresa. Foi identificado na Exatidão Express uma subutilização de recursos tecnológicos que podem já estar acessíveis a empresa através de sistemas já contratados. É recomendado que, além de adotar sistemas automatizados de acompanhamento de envios, que são comuns no mercado, as transportadoras invistam na busca e implementação de novas ferramentas tecnológicas em sua operação, que proporcionarão diferenciação e otimização.

A propriedade da infraestrutura da empresa não gera diferenciação no mercado por sua baixa importância para a operação e sua banalidade no mercado. Apesar disto, não a ter acarreta em custos fixos de aluguéis já que é impossível a realização do serviço sem a infraestrutura. Independentemente da estrutura ser própria ou alugada, a mesma deve sempre ser reformada ou substituída de maneira que contribua e comporte a operação e ainda possibilidades de expansão de forma que a empresa não tenha seu progresso impedido e sim impulsionado por este recurso. 
Independentemente de gerar ou não vantagem competitiva sustentável, por se tratar de itens básicos para garantir ao cliente a segurança do serviço prestado e a empresa e seus funcionários a seguridade em seu trabalho, todos os instrumentos de segurança cabíveis devem ser aplicados sempre que necessário e oportuno for. Isto gera um aumento dos custos, que deverá ser refletido na precificação do serviço. Quanto mais segurança oferecida, mais cara operação se torna. Para a manutenção da saúde das transportadoras e do setor em geral, é crucial que haja uma conscientização dos danos que as práticas de precificações combativas e concorrência predatória prejudicam todas as partes envolvidas.

A identidade empresarial se relaciona com o potencial de diferenciação através da especialização mencionado no parágrafo inicial deste tópico. Uma vez definidos os princípios da empresa e respondido as perguntas "A quem atender?" e "De que maneira atender?", a companhia terá definido seu nicho de atuação e a partir disso, deve buscar destaque e domínio neste espaço do setor de transporte de cargas rodoviárias. Desta maneira, será minimizado o impacto da realidade pulverizada e competitiva do mercado.

Para uma futura continuação do presente artigo ou então pesquisas de temas afins, recomenda-se a utilização de dados numéricos métodos estatísticos tanto na coleta quanto no tratamento de dados a fim de realizar comprovações quanto a efetividade das medidas e características analisadas. Além disto, seria interessante a aplicação deste estudo em médias e grandes transportadoras com o intuito de assegurar que as recomendações e conclusões se apliquem ao mercado de maneira geral. 


\section{Referências Bibliográficas}

SEBRAE. Entenda o motivo do sucesso e do fracasso das empresas. São Paulo, 2007. Disponível em: $<$ http://www.sebrae.com.br/sites/PortalSebrae/ufs/sp/bis/entenda-o-motivo-dosucesso-e-do-fracasso-dasempresas,b1d31ebfe6f5f510VgnVCM1000004c00210aRCRD> Acesso em: 19 de novembro de 2019.

Pequenas Empresas \& Grandes Negócios. Brasil é um país de empreendedores, aponta estudo da McKinsey. Rio de Janeiro, 2019 Disponível em:

https://revistapegn.globo.com/Empreendedorismo/noticia/2019/04/brasil-e-umpais-de-empreendedores-aponta-estudo-da-mckinsey.html> Acesso em: 23 de abril de 2020.

Serasa Experian. Brasil criou 2,5 milhões de empresas em 2018; mais de $\mathbf{8 0 \%}$ eram MEls. Rio de Janeiro, 2019 Disponível em: < https://g1.globo.com/economia/noticia/2019/03/26/brasil-criou-25-milhoes-deempresas-em-2018-mais-de-80percent-eram-meis.ghtml> Acesso em: 25 de abril de 2020.

RAMOS, P. TEORIA GERAL DE SISTEMAS. Administração Criativa, 29 mar 2013.

Disponível em: $<$ https://administracaocriativa.wordpress.com/2013/03/29/teoria-geral-desistemas/> Acesso em: 19 de novembro de 2019.

Truckpad. Modais de transporte: conheça os diferentes tipos. 2017. Disponível em: < https://blog.truckpad.com.br/transporte-rodoviario/modaistransporte-de-cargas/> Acesso em: 20 novembro 2019.

Confederação Nacional do Transporte. PIB do setor de transporte cresce o dobro do PIB do país em 2018. 2019. Disponível em: < https://cnt.org.br/agencia-cnt/pib-transporte-cresce-dobro-pib-brasil-2018 > Acesso em: 20 novembro 2019.

OLIVEIRA, J.J. Roubo de carga cria 'taxa de emergência' no frete. Valor Econômico, fevereiro de 2018. Disponível em: < https://valor.globo.com/empresas/noticia/2018/02/22/roubo-de-carga-cria-taxade-emergencia-no-frete.ghtml > Acesso em: 20 novembro 2019.

Roubos fazem seguro de cargas para o Rio triplicar de valor. Gazeta Online,

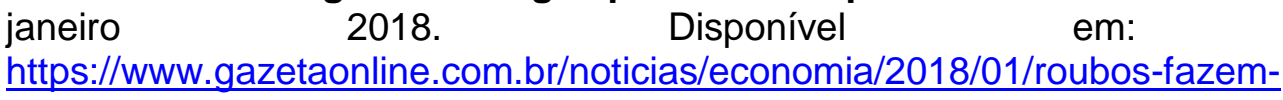
seguro-de-cargas-para-o-rio-triplicar-de-valor-1014114720.html > Acesso em: 21 de novembro de 2019.

CAGLIARI, A. Brasil desperdiça $44 \mathrm{mil} \mathrm{km}$ de rios que poderiam ser utilizados para transporte. Folha de São Paulo, outubro de 2019. Disponível 
em: < https://www1.folha.uol.com.br/mercado/2019/10/brasil-desperdica-44-milkm-de-rios-que-poderiam-ser-utilizados-para-transporte.shtml >Acesso em: 21 novembro de 2019.

Confederação Nacional do Transporte. Consumo de combustíveis cresce 5,2\% no Brasil, em 2014. Rio de Janeiro, 2015 Disponível em: $<$ https://cnt.org.br/agencia-cnt/aumento-consumo-de-combustiveis-2014-

gasolina-diesel-etanol-gnv-anp-10022015> Acesso em: 08 de maio de 2020.

Confederação Nacional do Transporte. Anuário CNT do Transporte. Rio de Janeiro, $2019 \quad$ Disponível em: <https://anuariodotransporte.cnt.org.br/2018/Rodoviario/1-2-1-/Empresas>

Acesso em: 03 de maio de 2020.

WIRED. Shipshape: Tracking 40 Years of FedEx Tech. São Francisco, CA EUA, 2013 Disponível em: <https://www.wired.com/2013/04/40-years-offedex/\#: :text=That\%20package\%20tracking\%20data\%20hit,the\%20location\%20 of\%20their\%20packages> Acesso em: 10 de junho de 2020.

Agência Nacional do Petróleo, Gás Natural e biocombustíveis. Série histórica do levantamento de preços e de margens de comercialização de combustíveis. Rio de Janeiro, 2015 Disponível em: < http://www.anp.gov.br/precos-e-defesa-da-concorrencia/precos/levantamento-deprecos/serie-historica-do-levantamento-de-precos-e-de-margens-decomercializacao-de-combustiveis> Acesso em: 12 de junho de 2020.

The Verge. Amazon is delivering half its own packages as it becomes a serious rival to FedEx and UPS. Rio de Janeiro, 2015 Disponível em: $<$ https://www.theverge.com/2019/12/13/21020938/amazon-logistics-prime-airfedex-ups-package-delivery-more-than-50-percent> Acesso em: 12 de junho de 2020.

PORTER, Michael E. Vantagem Competitiva. Rio de Janeiro: Campus, 1989.

KOTLER, P. \& KELLER, K. L. Administração de Marketing. São Paulo: Pearson, 2012.

OLIVEIRA, D. d. Planejamento Estratégico - Conceitos - Metodologia Práticas. Rio de Janeiro: Atlas, 2018.

Crepaldi, G. S., \& Crepaldi, S. A. Auditoria Contábil - Teoria e Prática. Rio de Janeiro: Atlas, 2019. 


\section{Anexo}

\subsection{Entrevista Qualitativa com Diretores/Presidentes da transportadora}

O profissional

01.Você pode contar brevemente seu histórico profissional e acadêmico?

02.Qual é o seu papel dentro da empresa hoje em dia?

A empresa

03.Qual a história da empresa?

04. Quantos funcionários trabalham na empresa?

05.Como é o desenho organizacional da empresa?

06.Como você descreve a operação da (nome da transportadora) a partir do momento que o cliente contrata a empresa?

07.Como é feita a prospecção de clientes e venda do serviço?

08.A empresa possui planejamento de médio e longo prazo? Como ele é feito?

09.Quais são as principais forças da sua empresa? E as principais fraquezas/pontos de melhora?

O mercado

10.Como você vê a concorrência entre transportadoras?

11.Quem são seus principais concorrentes?

12.Como sua empresa se posiciona no mercado em relação a eles?

Quais os diferenciais?

13.Você conhece algum serviço adicional ou característica de algum concorrente que considere valiosa? Gostaria de aplicar na (nome da transportadora)?

14.Para você, quais são os principais desafios para uma empresa do setor? 


\subsection{Entrevista Qualitativa com Funcionários da transportadora}

O profissional

01.0 que você faz na empresa hoje?

02. Quantos funcionários respondem a você?

03. Você pode contar brevemente seu histórico profissional e acadêmico?

04. Você já fez/recebeu algum curso/capacitação para sua função atual?

A empresa

05. Como você descreve a operação da (nome da transportadora) a partir do momento que o cliente contrata a empresa?

06. Existe algum indicador de performance ou alguma métrica relacionada a seu trabalho? Qual? Como ela funciona?

07.Quais são as principais forças da sua empresa? E as principais fraquezas/pontos de melhora?

O Mercado

08. Como você vê a concorrência entre as transportadoras?

09.Quais são os principais concorrentes da empresa atualmente?

10.Como sua empresa se posiciona no mercado em relação a eles? Quais os diferenciais?

11. Você conhece algum serviço adicional ou característica de algum concorrente que considere valiosa? Gostaria de aplicar na (nome da transportadora)?

12.Para você, quais são os principais desafios para uma empresa do setor? 


\subsection{Entrevista Qualitativa com Clientes da transportadora}

Informações relativas à relação com a transportadora contratada

01.Como foi seu primeiro contato com a (nome da transportadora)?

02. Como é o processo a partir da tomada de decisão do transporte ser realizado pela (nome da transportadora) até a conclusão do serviço?

03.Em uma escala de 0 a 10, Como você avalia o serviço prestado pela (nome da transportadora)?

04.Tendo conhecimento de outras transportadoras concorrentes, como você classificaria a (nome da transportadora) em relação aos seus concorrentes?

05.Quais os pontos fortes que você identifica na (nome da transportadora)? E quais os pontos passíveis de melhora? Listar em ordem de importância

Informações relativas à contratante

06.Como é a sua demanda logística atendida por transportadora(s)?

07.Como funciona o processo de escolha da transportadora para um serviço/operação?

08.Quais os critérios envolvidos nesse processo? Poderia listar em ordem de importância?

09.Quais características você procura em uma transportadora e em sua operação?

10.0 que é necessário para que o serviço de uma transportadora atenda suas expectativas? E o que faria com que o serviço exceda suas expectativas?

11.Sua área faz uso de algum indicador de performance relacionado a logística/transportes? Quais? Como funcionam? 